\title{
IMPLEMENTATION OF PUBLIC SERVICE POLICY TO IMPROVE THE SERVICE QUALITY OF SISINGAMANGARAJA XII INTERNATIONAL AIRPORT
}

Tunggul Sihombing,

Faculty of Social and Political Sciences, University of North Sumatera, Indonesia

\section{Elita Dewi,}

Faculty of Social and Political Sciences, University of North Sumatera, Indonesia

\section{Deddy Hutapea,}

Faculty of Social and Political Sciences, University of North Sumatera, Indonesia
Received: October 19, 2021

Accepted: November 22, 2021

Published: January 17, 2022

Corresponding Authors: tunggul@usu.ac.id

DOI: $10.53947 /$ tspj.v1i2.71

\begin{abstract}
The airport is the entrance to an area, region, or country and is the primary means of air transportation. Sisingamangaraja XII International Airport is a State-Owned Enterprise (BUMN) under the auspices of PT Angkasa Pura II. Sisingamangaraja XII International Airport has a public service standard policy as a form of commitment to users. In implementing public service standards policies, there are several challenges in improving the quality of public services. This study aims to identify and describe the implementation of public service standards policies at Sisingamangaraja XII International Airport.
\end{abstract}

This study uses descriptive research methods through a qualitative approach. In collecting data, the researcher used the method of interview, observation, documentation using the theory of Van Meter and Van Horn. The theory consists of variables that can determine the effectiveness of implementation, namely policy standards and objectives, relationships between organizations, resources, characteristics of implementing agents, social, political, and economic conditions, and disposition of implementers.

This research shows that the orientation of the implementation of public service standard policies at Sisingamangaraja XII International Airport is public satisfaction. The airport manager makes some effort, such as the provision of digitalbased facilities, service efficiency, availability of facilities that are orientated to standards, and accordance with the availability of resources, characteristics of implementer organization, economic, social, and political conditions. However, the airport management is still experiencing problems in several aspects, such as coordination with related organizations and partnerships that have not been effective and the political impact of refusing to change the airport's name by the local community.

Keywords: Implementation, Public Policy, Standard of Public Policy 


\section{Introduction}

Advances in technology and information can change the way people live to meet their needs easily and quickly. In addition to the need for goods, the need for services is also needed by the community. However, the market segment that does not recognize social strata makes the scope of the service market very broad. Service products do not recognize the time and territorial limits in marketing. With broader reach and coverage of information technology, services can be marketed anytime and anywhere according to the community's needs.

People's mobility is getting faster, followed by an increasing flow of goods. Thus, the need for transportation facilities also increases. Therefore, services that can meet the mobility needs are also do needed. Transportation services often used today are air transportation, which requires airports as the gateway to an area, region, or even country. The airport is also a symbol of its prestige, creating a distinct impression for domestic and international airplane passengers. Even today, excellent airport services reflect tourism services, considering that airports are the gateway for passengers to enter and leave and accommodate several activities such as recreation, entertainment, and the tourism information service center.

In carrying out its functions, airports must be arranged in an integrated manner. Thus, services to consumers can be appropriately provided and follow the expectations of consumers themselves. Rules regarding the operation of airports in Indonesia are adjusted to the Minister of Transportation Decree No. 48 of 2002 concerning the Implementation of Public Airports (Peraturan Menteri Perhubungan No. 48 Tahun 2002 Tentang Penyelenggaraan Bandar Udara Umum, 2002). The regulation aims to realize the implementation of reliable and skillful flight operations following the Indonesian Standardization Agency (SNI) and the International Civil Aviation Organization (ICAO) standards.

The Government of Indonesia owns Sisingamangaraja XII International Airport and is fully managed by PT Angkasa Pura II. As the operator of the airport, PT Angkasa Pura II completes the airport with several facilities, such as airport bus schedule display, e- payment at commercial tenants, Wifi area, bus ticketing vending machine, smart baggage, tourism information, kiosk, self-check-in, and apps at the check-in counter, where all users airport services can access these facilities. According to The President Director of PT Angkasa Pura II, Muhammad Awaluddin, in a written statement to Kompas.com on Friday, November 3, 2017, explained that all digital facilities were 100 percent ready to use, including airport Wifi facilities that can be used by service users, where the Wifi speed reaches $100 \mathrm{Mbps}$.

Public services are activities in the context of fulfilling basic needs by the civil rights of every citizen and resident in the form of goods or services or administrative services organized by public service providers. Public service standards are guidelines for service delivery and a reference for assessing service quality as a commitment to providing public services. Therefore, public service standards will certainly optimally run if accompanied by airport readiness, both from the 
application of digital systems, resources, and policies/sanctions regarding irregularities that occur.

In the context of this research, Sisingamangaraja XII International Airport is known to have received the Prima Madya Award. According to data analysis, the service at this airport is still not optimal due to the limited capacity of the waiting room ("Bandara Silangit Dan FL Tobing Tingkatkan Pelayanan," 2016). However, the quality of service at Sisingamangaraja XII International Airport can still be improved, considering that there are challenges faced by airport managers, such as limitation of waiting room capacity, unavailable waiting room dividers between airlines, and the quality of airport staff resources. Some of which come from around of the area, who do not yet have adequate qualifications, and many more. Implementing public service standards in the field of services at Sisingamangaraja XII International Airport is undoubtedly more optimal if it is accompanied by readiness from the airport, both from the application of digital systems, resources, and policies/sanctions regarding irregularities that occur.

This finding can be an aspect that can be improved, considering that Sisingamangaraja XII International Airport is the most strategic transportation infrastructure in the Lake Toba National Tourism Strategic Area. This finding can be an aspect that can be improved, considering that Sisingamangaraja XII International Airport is the most strategic transportation infrastructure in the Lake Toba National Tourism Strategic Area. Based on this, researchers researched the implementation of public service policies in improving the quality of public services at Sisingamangaraja XII International Airport In The Lake Toba National Tourism Strategic Area.

\section{Research Method}

This study used the descriptive qualitative method. This study used the descriptive qualitative method. Sugiyono $(2015$, p. 9) proposed that the qualitative descriptive approach is a research method by examining surrounding objects, where the researcher is the key instrument, while the data collection technique is carried out by the interview method, the data analysis is inductive. The research results tend to be substantial, not a general phenomenon.

This research is located at Sisingamangaraja XII International Airport, Siborongborong District, North Tapanuli Regency. This location was chosen because the researchers want to figure out the obstacles airport managers face, such as waiting room capacity, unavailable waiting room dividers between airlines, the quality of airport staff resources, and many more reasons.

The vital factor in this research is the informant. According to Marshall and Rossman in Creswell and Creswell (2018, p. 278), informants whom researchers in research have selected are needed to know the perspectives and meanings through the interactions carried out during the research. The informants in this study consisted of Executive General and Staff Employees of Sisingamangaraja XII International Airport, Head of the North Tapanuli Regency Transportation Service, Head of North Tapanuli Regional Development Agency, service users of Sisingamangaraja XII International Airport, and the local community. 
Then, this study's data collection techniques used the interview method through interview guidelines. According to Bungin (2015, p. 134), the interview method can be done through face-to-face dialogue between the interviewer respondent, with or without guidelines. In addition, the researcher uses the documentation method as additional information in this study. Creswell and Creswell (2018, p. 276) explain that good documentation requires a protocol to document the problem in detail and develop a thorough case study database. Therefore, researchers develop documentation guidelines following the concepts or variables in theory used in discussing research problems.

Meanwhile, data analysis techniques are used to process research results obtained previously through data collection that has been carried out. The data obtained then analyzed the interactive model developed by Miles and Hubermen in Idrus (2009, p. 148), consisting of three analysis components: data reduction, data presentation, and conclusions.

\section{Theory And Concept}

\section{- $\quad$ Policy Implementation}

According to Shafritz et al. (2017, p. 57), implementation puts a government program into effect; it is the complete process of translating a legal mandate, whether an executive order or an enacted statute, into appropriate program directives and structures that provide services or create goods. In public policy implementation, policy implementation must refer to the implementation model to achieve policy objectives. Snellen (2014, p. 90) argues that for a successful implementation, the willingness of street-level bureaucrats and officials to make the designed policy has to be estimated and the willingness to accept the policy among the target groups. Based on the explanation above, the author concludes that public policy is a benchmark for the direction to take or not to take specific actions to move all sectors or government apparatus and create changes in the lives of those affected by the policy.

Public policy implementation has several theories known as public policy implementation models. In this study, the authors use the policy implementation model proposed by Van Meter and Van Horn. According to Van Meter and Van Horn (1975, p. 462), there are several variables in the policy implementation model, including: (1) Policy Standards and Objectives; (2) Policy Resources; (3) InterOrganizational Relations; (4) Characteristics of Implementing Agents; (5) Social Economic and Politic Conditions; and (6) Implementer's Disposition. The authors believe that the Van Meter and Van Horn implementation models are appropriate for this study because this model explains the achievements and constraints of service standards. This policy implementation chooses because this model is oriented to actors' attitudes, behavior, performance, and socio-economic-political conditions in policy implementation. 


\section{- Public Service}

According to Holzer and Schwester (2019, p. 552), Public service is an effort made to realize ethical principles in the procurement of goods and services to the community for social justice, such as the development of public spaces, education, public health, justice and security, environmental protection, and others. In Indonesia, the public services are organized by the Government Law No. 25 of 2009 concerning Public Services (Undang-Undang No. 25 Tahun 2009 Tentang Pelayanan Publik., 2009). The law describes public services as activities in the context of fulfilling service needs by laws and regulations for every citizen and resident of goods, services, or administrative services provided by public service providers. Every public service must have service standards and certainty for service recipients. Dwiyanto (2011, p. 37) stated that service standards are critical in developing the state service system, whether regulating service input, process, or output.

Public services must have specific standards to bring public satisfaction. According to Ridwan and Sudrajat (2009, p. 103), every public service delivery must have service standards and be published as a guarantee of certainty for service recipients, where public service standards refer to service procedures, completion time, service costs, service products, facilities, and infrastructure, and the competence of service providers.

\section{- Public Satisfaction}

Public satisfaction is one of the references used to assess the success of policy implementation. Morgeson III $(2014$, p. 98) argues that four variables in the model are hypothesized to affect public satisfaction: process, information, customer service, and citizen expectations. In de Ona and de Ona (2015, p. 2), Oliver describes public satisfaction as an affective judgment (liking/pleasure) purely experiential, defined as the 'consumer's fulfillment response.

According to Wirtz and Lovelock (2016, p. 170), primary factors can determine public satisfaction with a service known as the eight-petal service model, including information, consultation, undertaking, hospitality, caretaking, exceptions, billing, and payment. Wirtz and Lovelock (2016), makes the explanation the variables of the eight-petal service model:

1) Information: Quality service starts from product information and services that customers need. The provision of fast and precise information channels makes it easy for customers to meet their needs;

2) Consultation: After obtaining the information, technical consultations, prices, procedures, and policies are carried out with the service personnel. For this reason, time, consultation materials, personnel, and other facilities must be prepared quickly and completely;

3) Order taking: after customers get compliance with their needs, application, and administrative services are uncomplicated, flexible, low-cost, light terms, and other service conveniences; 
4) Hospitality: as a polite, friendly service attitude and behavior, a healthy and beautiful room, for example by providing healthy and clean toilets;

5) Caretaking: the ability to adjust services to the different backgrounds of the people. For example, the availability of parking spaces for people who own vehicles, or the provision of applications for those who cannot read and write;

6) Exceptions: the ability of the service to be responsible for public claims for products that are not of good quality and detrimental, for policies that benefit specific groups and harm other groups;

7) Billing: administration of payment for public services that make it easier for the people in terms of forms, payment mechanisms, and accuracy of calculations; and

8) Payment: payment facilities based on the customer's wishes, either in self-service payments, bank transfers, credit cards, direct debits, or direct bills during transactions. All of them must make it easy and according to the people's ability to pay.

The above discussion shows that service quality is feedback users give to service providers for the services provided. So, it can be concluded that the quality of service can be known through the perception of people who use a service.

\section{- $\quad$ Airport}

According to Annex 14 of ICAO (International Civil Aviation Organization), an airport is a particular area on land or water (including buildings, installations, and equipment) intended either in whole or in part for the arrival, departure, and movement of aircraft (Annex 14 - Aerodromes - Volume I: Aerodrome Emergency Planning Section, 2018). In the context of Indonesia, based on Government Regulation of the Republic of Indonesia Number 70 of 2001 concerning Airports, the definition of an airport is an airport used for landing and taking off aircraft, and boarding and dropping passengers or loading and unloading cargo or post, which is equipped with safety flight facilities (Peraturan Pemerintah No. 70 Tahun 2001 Tantang Kebandarudaraan., 2001).

Airports in Indonesia have specific functions and are regulated in-laws and regulations. According to Law no. 1 of 2009 concerning Aviation and Regulation of the Minister of Transportation No. 69 of 2013 concerning the National Airport Arrangement (Peraturan Menteri Perhubungan No. 69 Tahun 2013 Tentang Tatanan Kebandarudaraan Nasional., 2013), The airports have the following functions: (1) A node in the air transportation network which is described as an airport location point where several networks and flight routes meet according to the airport hierarchy; (2) Gateway to economic activity in an effort to distribute development, growth and economic stability as well as to harmonize national development and regional development which is described as the location and area around the airport that becomes the entry and exit point for economic activity; (3) The place for the activity of changing modes of transportation, in the form of interconnection between modes at the transportation node in order to meet the demands for improving the quality of integrated and sustainable services which is described as a place for transferring modes of air transportation to other modes of transportation or vice versa; (4) The 
driving force and support for industrial, trade and/or tourism activities in driving the dynamics of national development, as well as integration with other development sectors, is described as an airport location that facilitates air transportation in the surrounding area; (5) Opening of regional isolation, described by the location of airports that can open isolated areas due to geographical conditions and/or because of the difficulty of other modes of transportation; (6) Development of border areas, described by the location of airports taking into account the priority level of development of the border areas of the Republic of Indonesia in the islands and/or on the mainland; (7) Disaster management, described by the location of the airport that takes into account the ease of air transportation for handling natural disasters in the surrounding area; and (8) Infrastructure to strengthen the Archipelago Insight and the sovereignty of the state, illustrated by the location points of the airport which are connected to the network and flight routes that unite the territory and sovereignty of the Republic of Indonesia.

\section{Result And Discussion}

Implementing the policy to improve service quality at Sisingamangaraja XII Airport is a significant effort considering that the airport is located in Lake Toba's National Tourism Strategic Area (KSPN). Based on the Integrated Tourism Masterplan For Lake Toba area covers eight Gulf Stream, namely Simalungun Regency, Karo Regency, Dairi Regency, West Phakpak Regency, Humbang Hasundutan Regency, Samosir Regency, Toba Samosir Regency, and North Tapanuli Regency, Where the economic objective of the determination of Lake Toba as a KSPN is to develop an area that has the potential to spur economic growth in the region and the surrounding area as well as to encourage equitable distribution of regional development. Thus, Sisingamangaraja XII International Airport is expected to become the main gateway for domestic and international tourists.

The author uses the Van Meter and Van Horn policy implementation model, which consists of six variables, including (1) Policy Standards and Objectives; (2) Policy Resources; (3) Inter-Organizational Relations; (4) Characteristics of Implementing Agents; (5) Socio-economic and Political Conditions; and (6) Implementer's Disposition. The authors think it can offer a framework that explains and analyzes how implementing public service standards policies at Sisingamangaraja XII International Airport through the Van Meter and Van Horn implementation models. The Van Meter and Van Horn, policy implementation model, have a very complex model, where one variable can affect other variables, as stated by Indiahono (2009, p. 38), namely:

a. Resource variables can affect the social, economic, and political environment;

b. Resource variables also can affect communication between implementing agencies;

c. Variables of the social, economic, and political environment can influence the characteristics of the implementing agency;

d. Variables of the social, economic, and political environment can influence the attitude of the implementer; 
e. Social, economic, and political environment variables can influence policy performance;

f. Communication between implementing agencies has a mutually influencing relationship with the characteristics of implementing agencies;

g. Communication between implementing agencies can influence the attitude of implementers;

h. The characteristics of the implementing agency can influence the attitude of the implementer;

i. The characteristics of the implementing agency can also directly affect policy performance.

Thus, through this research, the author can describe the problems faced by airport managers and analyze things that can be done to improve the quality of services through implementing integrated policies and involving all stakeholders involved, including service users and the local community.

\section{- $\quad$ Policy Standards and Objectives}

The standards and objectives must be clear and directed and based on the main interests of the systems that can determine policy achievement. In the ongoing policy process (implementation), policy standards and objectives must be measurable to be realized. If there are vague standards and policy targets, there will be multiple interpretations, and it is easy to cause conflict between implementation agents, as stated by Van Meter and Van Horn in Subarsono (2005, p. 99). The policy must be clear what the standards and objectives of the policy are for measurement.

Service Standards at Sisingamangaraja XII International Airport have been mandated in Law Number 25 of 2009 concerning Public Services based on the Executive General Manager Decision of Sisingamangaraja XII International Airport Number: KEP.13.01/13/04/2018/007 concerning Service Standards at Sisingamangaraja International Airport XII (Keputusan General Manager Bandara Internasional Sisingamangaraja XII No.KEP.13.01/13/04/2018/007 Tentang Standar Pelayanan Di Bandara Internasional Sisingamangaraja XII, 2018). The compiled service standards have indicators for achieving them, namely timeliness, affordable costs, service availability, and satisfaction, without leaving the legal aspect in its implementation and prioritizing good service to service users. The compiled service standards have indicators for achieving them, namely timeliness, affordable costs, service availability, and satisfaction, without leaving the legal aspect in its implementation and prioritizing good service to service users.

According to the Assistant Manager of Airport Operation \& Service, the explanation of service policy standards at Sisingamangaraja International Airport XII according to the Assistant Manager of Airport Operation \& Service is assessed through a survey held every year, including Airport Service Quality, Customer Service Person Number, and Metro Motor Scores. According to the Assistant Manager of Airport Operation \& Service, Sisingamangaraja XII International Airport always gets a better score than the standards set based on the survey. In addition, the Assistant 
Manager of Airport Operation \& Service stated that public service standards at Sisingamangaraja XII International Airport are regulated through the Service Operational Standards (SOP) for Public Services. However, drafting the SOP has not included the community as mandated by Law 25 of 2009 article 22 paragraph 1 (Undang-Undang No. 25 Tahun 2009 Tentang Pelayanan Publik., 2009). However, the SOP and the Service Declaration at Sisingamangaraja XII International Airport have been socialized. So it can be concluded that the implementation at Sisingamangaraja XII International Airport has reached 100 percent.

The implementation of service policy standards at Sisingamangaraja XII International Airport can also be seen through facilities and infrastructure services, check-in areas, and waiting room displays, including information screens. According to Sisingamangaraja XII International Airport Information Staff, the target of implementing the service system must meet criteria, such as punctual check-in, can save time and costs, especially for passengers who come from areas around the airport, such as North Tapanuli, Humbang Hasundutan, West Phakpak, Dairi, Toba Samosir, and Samosir.

The Airport Service Supervisor also supervises the implementation of services at the airport. According to the representative of Sisingamangaraja XII International Airport Service Supervisor, service supervision is carried out by the Terminal Inspector Service unit (TIS), where this unit serves inspections in the check-in room and security while in the airport terminal area. The service standards include friendliness and maintaining good interactions with the passengers, including the service users or 3S (Senyum, Sapa, Salam).

Based on the results of interviews with airport authorities, it is known that the implementation of service policies at Sisingamangaraja International Airport has standards that have been regulated in Law Number 25 of 2009 concerning Public Services (Undang-Undang No. 25 Tahun 2009 Tentang Pelayanan Publik., 2009) also Executive General Manager Decree of Sisingamangaraja International Airport XII Number: KEP.13.01/13/04/2018/007 concerning Service Standards (Keputusan General Manager Bandara Internasional Sisingamangaraja XII No.KEP.13.01/13/04/2018/007 Tentang Standar Pelayanan Di Bandara Internasional Sisingamangaraja XII, 2018). The regulation contains indicators that serve as service standards applied by all airport officers, namely punctuality, affordable costs, availability of services with community satisfaction without leaving the legal aspect in its implementation, and prioritizing the best service to customers.

The author also interviewed visitors and service users as elements that became the object of service at Sisingamangaraja XII International Airport. The people interviewed assessed that the services and facilities at Sisingamangaraja XII International Airport were good. In addition, the airport's strategic location makes passengers from the surrounding area prefer to fly from Sisingamangaraja XII International Airport rather than Kualanamu International Airport, which is the largest airport in North Sumatra Province due to lower costs. In addition, the public also views that the check-in process to boarding the plane is also not inferior, especially compared to Kualanamu International Airport. The service user 
community also assesses the service quality of Sisingamangaraja XII International Airport has also been much better after it has the status of an international airport.

This assessment is equivalent to data on the number of passengers and cargo served by Sisingamangaraja XII International Airport. Based on these data, the number of aircraft movements in 2014 reached 1282 times and increased to 4878 times in 2018. The increase in aircraft movements was also followed by passengers and cargo, namely 24,005 people in 2014 , which increased to 425,476 people in 2018 , and 0 kilograms of cargo in 2014 increased to 350,167 kilograms.

Based on the explanations above, the authors stated that the standards and targets related to the quality of public services at Sisingamangaraja XII Airport are very effective and efficient, no less competitive with services at other international airports. It is just that the provision of facilities is still inadequate because, as is known, Sisingamangaraja XII International Airport is still under construction.

\section{- $\quad$ Resources}

A resource is a potential possessed in a specific element and is indispensable in carrying out a specific purpose. The implementation process depends on the successful use of resources. Resources are not always physical but also non-physical valuable resources to support the policy implementation process. Policy implementation needs the support of human resources and non-human resources.

In the context of service delivery, human resources can be seen as physical resources that support a particular program or policy in the policy implementation process. In addition to the human resources needed to support implementing these public service standards, physical resources in the form of facilities always support implementing a policy. The existence of physical resources will make it easier for a policy to run according to its objectives.

The form of support from the airport that will still be needed is implementing socialization and promotion. However, with the resources that serve under the Service Standards and SOPs, the services at Sisingamangaraja XII Airport will not be less competitive with the resources at other international airports. According to the Assistant Manager of Airport Operation \& Service at Sisingamangaraja International Airport XII, the quality of human resources in implementing public service standards is adjusted through the pattern of the right man in the right place. Every personnel placed in the operations, service, and technical provision sectors is provided with a Personnel Proficiency Certificate (Surat Tanda Kecukupan Personil) given by the Directorate General of Civil Aviation in their respective fields. The airport has also implemented a recruitment system that is free from elements of nepotism but is based on established qualifications such as company procedures.

Service personnel at Sisingamangaraja XII International Airport have various educational backgrounds. According to data provided by Sisingamangaraja XII International Airport to the authors in 2020, there are 109 employees at Sisingamangaraja XII International Airport with details of high school education as many as 63 people, 14 diploma, 14 diploma, and 31 bachelors people. Meanwhile, the essential field employees at Sisingamangaraja International Airport XII consist of 2 
personnel for Customer Service, five personnel for aircraft maintenance center, 14 personnel for aviation accident relief and firefighters, eight personnel for aviation security, four personnel for airport electrical and mechanical facilities, six personnel for airport general engineering facility, and four personnel for airport electronics.

Then, according to the Airport Security Supervisor, all officers and service employees at Sisingamangaraja XII International Airport were given introduction and training on service excellence or how to provide excellent service to service users. So, before carrying out their duties, all stakeholders at Sisingamangaraja XII International Airport have been provided with the basics of providing services that prioritize excellent service.

Of course, the performance of human resources at Sisingamangaraja XII Airport is intensely felt by service users. According to service users interviewed, the quality of human resources and infrastructure at Sisingamangaraja XII International Airport is generally reasonable. These aspects are related to services in the airport and terminal area, the check-in process, and the hospitality service officers provide to all prospective passengers. In addition, service users at Sisingamangaraja XII International Airport feel that the services provided are not discriminatory or based on social or economic background.

In addition to human resources, Sisingamangaraja XII International Airport is also equipped with several infrastructure resources to facilitate service to all service users. In this regard, the researcher conducted interviews with service users who concluded that the service at Silangit International Airport XII is quite good with the existing facilities, quite comfortable with the existing facilities. However, it is still very lacking for international standards. However, it will gradually improve with the development process already in the 2019 Work Plan.

\section{- $\quad$ Relations between Implementing Agencies}

The relationship between organizations is a factor that strongly supports the success of a program or policy. In achieving the goals and objectives of a policy, it is necessary to have a good form of coordination and cooperation between related organizations. Implementation will be effective if the measures and goals are understood by the individuals responsible for their achievement. Besides, the relationship between organizations is an essential indicator because, without good inter-organizational communication, the policy implementation process will run well and vice versa.

The success of policy implementation requires that the implementor knows what must be done to implement the program or policy. What are the actual goals and objectives of the policy that must be transmitted to the target group? Clarity of goals and objectives in a policy also affects coordination and cooperation between agencies. Because the goals and objectives of a policy are not clear, then the relationship between the relevant agencies in the process with the policy will not work well.

Then, implementing the policy (implementation) can run effectively is primarily determined by the relationship between organizations carried out by the 
implementers of the policy accurately. In addition, cooperation and coordination with related agencies is a mechanism that can make an implementation run well. With better coordination of communication with related parties, implementing the policy (implementation) will run well, and mistakes will be anticipated, and vice versa.

According to the Assistant Manager of Airport Operation \& Service at Sisingamangaraja XII International Airport, the airport communicates with several agencies such as Bappeda, the Regional Government, especially Siborongborong District, the Department of Transportation, and the Department of Tourism and Culture. Communication with relevant agencies is carried out through coordination forums to handle several things, such as passenger flow, fulfillment of service standards at Sisingamangaraja XII International Airport, and handling related to significant holiday celebrations, such as the new year, Eid al-Fitr, and others. Meanwhile, according to the Head of the Tourism and Transportation Facilities and Infrastructure Sub-Division of the North Tapanuli Regional Development Planning Agency, coordination with the management of Sisingamangaraja XII International Airport has been established for a long time, especially with local government at the time of land acquisition for the expansion of the airport area. Coordination meetings are also held every three months when the airport is not international. However, coordination every three months is no longer carried out after PT Angkasa Pura II operates Sisingamangaraja XII International Airport. Then, according to the Siborongborong sub-district head, coordination with the airport is very fluid. The airport manager and the sub-district always hold meetings every three months to build relationships and coordinate the flow of arrivals and departures, especially on religious holidays. Coordination in terms of handling arrival and departure flows also carried out by the manager of Sisingamangaraja XII International Airport with the North Tapanuli Regency Transportation Service, where according to the Head of Technical Facilities and Infrastructure of the Transportation Service, the coordination relates to the flow of vehicles from and to the airport and air traffic flow. at Sisingamangaraja XII International Airport.

Coordination between implementing agencies does not have to be regulated in public service standards but depends on superiors or the event to be carried out even though it is not on the annual agenda. Concerning inter-organizational relations, the Head of the Section for Data Processing Integration and Statistical Dissemination of the Central Statistics Agency of North Tapanuli Regency has a good relationship with airport management, mainly routine data collection.

Thus, the relationship between organizations related to the public service standard policy of Sisingamangaraja XII International Airport has so far coordinated with relevant agencies/services in North Tapanuli in conducting socialization as a manifestation of the policy implementation process. The coordination carried out by Sisingamangaraja XII International Airport with related agencies is indeed not on the annual agenda, but there is always good communication if there is an event that will be held implemented. So, it can be said that corporate relations between related agencies are still running less effectively because Sisingamangaraja XII International Airport does not make an annual agenda. 


\section{- Characteristics of Executing Agent}

Characteristics agents include anyone involved in a program, the policy included inside, outside organizational structure of the policy, all of which will affect the implementation of a policy. According to Van and Van Horn in Subarsono (2005, p. 100), the characteristics of implementing agents include the bureaucratic structure, all of which will affect the implementation of a policy. The focus on implementing agencies includes formal and informal organizations involved in implementing the policy. Character is significant because policy implementation performance will be influenced by the suitable characteristics and matches the implementing agents.

Regarding the implementation of public service standards at Sisingamangaraja XII International Airport, those involved in the implementation are Sisingamangara XII International Airport, Regional Development Planning Agency, Regional Government, especially Siborongborong Sub-district, Transportation Service, Central Statistics Agency, Tourism and Culture Office, local community, and airport service users in Sisingamangaraja XII International Airport as the target of implementing this policy.

The Assistant Manager of Airport Operation and Service explained that all the implementing agencies have the same characteristics to improve service quality and handle the flow of arrivals and departures, especially on religious holidays. Thus, airport managers and relevant government agencies coordinate regularly and maintain inter-agency relations through non-formal relationships. Besides, the airport management also maintains good relations with all airlines serving destinations to and from Sisingamangaraja XII International Airport so that both airports and airlines can collaborate in carrying out service principles following applicable regulations.

\section{- Socio-Politic and Economic Conditions}

The vital thing to consider in assessing the performance of policy implementation is the extent to which the external environment contributes to the success of public policies. This external environment can determine the consistency in the performance of policy implementation. An unfavorable external environment can be the root cause of the failure of policy implementation. Therefore, efforts to implement policies must also pay attention to the conducive conditions of the external environment. Social, political, and economic conditions are factors that can support interest groups in the form of support for policy implementation, the characteristics of the participants, namely supporting or rejecting, what is the nature of public opinion in the environment, and whether the political elite supports the implementation of policies as stated by Van Meter and Van Horn in Subarsono (2005, p. 101). So, the thing that could be considered in assessing the performance of public policy implementation in this variable is which the external environment can contribute to the success of the public policies that have been established, including the conduciveness of the external environment to determine the performance of policy implementation. 
According to the Assistant Manager of Airport Operation and Service at Sisingamangaraja XII International Airport, tourists can use this airport to visit tourist destinations within the National Tourism Strategic Area of Lake Toba or when returning to their origin city. The Assistant Manager of Airport Operation \& Service explained this could be seen through the increase in the number of passengers at this airport every year with an average of 1200 passengers every day. Meanwhile, the Sisingamangaraja XII International Airport staff describe how this airport became the regional people's choice when they wanted to use air transportation, especially in Jakarta. People choose this airport because of the cheaper cost of departing from Kualanamu International Airport in Deli Serdang Regency.

The local government has also begun to feel the increase in economic activity from Sisingamnagaraja XII International Airport. According to the Head of Technical Facilities and Infrastructure of the North Tapanuli Regency Transportation Service, the existence of this airport facilitates the mobility of the local community. It significantly brings in tourists from outside the region, increasing the local community's income.

The people interviewed revealed that the existence of this airport has more positive impacts on the economic development of the community. After the airport became an international standard, tourist arrivals increased and spurred people to open new businesses, such as warungs, restaurants, hotels, and local businesses. In addition, local people who work at this airport feel that their economic level had increased, especially when farm laborers before the airport started operating. The head of Silangit Village also recognized the improvement in the community's economy. According to him, the people around the airport no longer only work as farmers but have other options to open businesses, support tourism activities, and do food. However, according to the Head of Silangit Village and the local public, the renaming of Silangit Airport to Sisingamangaraja XII International Airport has received mixed responses. Not a few people support changing the name to become a national hero from the Batak Land, but people from the Silangit area feel that the name change seems to eliminate the element of the airport's location.

Thus, the socio-economic and political conditions in implementing this program are going well, as evidenced by the increase in visits to the Lake Toba National Strategic Area and the people. They accept the presence of Sisingamangara XII International Airport and support the implementation of public service standards because they feel the benefits.

\section{- Implementer Dispotitions}

The disposition of the implementor is the attitude or tendency of the implementers to accept or reject a policy. The attitude of accepting or rejecting the implementing agency will significantly affect the success of the public policy, as stated by Van Meter and Van Horn in Agustino (2006, p. 94). Disposition refers to characteristics closely related to policy implementers, such as understanding of policies, responses to policies, and the intensity of implementors. A good, fair, and honest attitude and providing good service to the community will implement a policy according to plan. 
Community participation as the target of a policy is also determined through the disposition or attitude of the implementor. If the attitude of the implementers is terrible, the participation of the community is reduced, but if the implementers are kind, honest, and nurturing, then the community will also participate in the success of the policy. The implementing agents reflect the form of assessment of an agency. The attitude shown by the implementers in providing services to the community is an indicator of assessment for an agency that can influence the policy implementation process.

Sisingamangaraja XII International Airport as the implementer of the policy should provide the best service in serving service users. The best service proves that the attitude shown by the implementor, namely Sisingamangaraja XII International Airport, is to support the implementation of public service standard policies. Response in serving the community is a picture of attitude tendencies in policy implementation. In this case, Sisingamangaraja XII International Airport provides the best service to customers or the public, both in departure, arrival, and when responding to complaints from customers appropriately and providing robust data regarding customer complaints. According to the Assistant Manager of Airport Operation \& Service, all criticisms and inputs given by service users at this airport have always been the central aspect for managers in improving the service quality. In addition, if there are reports from the public regarding actions taken by service officers that are not pleasing to service users, they will be followed up intensively, from asking information to imposing sanctions, both administratively to the removal of the position of the person concerned. However, all airport officers have never done anything wrong or had a bad performance. Instead, the criticism and suggestions given by the community are more input for improving the quality of airport services. Besides, according to the Airport Security Supervisor, officers who carry out all tasks by complying with operational standards that have been applied have never received complaints from the public, especially service users. However, if the officers still commit violations, the airport supervisor will be given a sanction if it is proven that there is a violation in serving airport service users.

Thus, the implementor's disposition or the implementer's attitude in providing services is to provide the best possible service in responding to requests and complaints from users who want to leave and those who come. Based on the researchers' observations, the response of the implementers in serving the community was outstanding and swift. The attitude of the implementers towards this program also determines the process of implementing public service standards at Sisingamangaraja XII International Airport. The attitude shown by the implementers is to support the process of implementing this program, as evidenced by the response of implementing agents in providing services to service users. So it can be concluded that the disposition of the implementor is to support the implementation of public service standard policies.

\section{Conclusions}

Based on the results and discussion in the previous chapter, it can be concluded that the implementation of the Public Service Policy in improving the service quality 
of Sisingamangaraja XII International Airport, in general, has been running thoroughly. However, there are also still some obstacles such as the lack of facilities and infrastructure, such as lack of waiting rooms, lack of check-in rooms and other facilities, lack of coordination with agencies, and coordination with partnerships that have not been effective so that it can be said that this program has not been appropriately implemented. The implementation of Public Service Policies in improving the service quality of Sisingamangaraja XII International Airport in Silangit District, North Tapanuli Regency in the Lake Toba National Tourism Strategic Area can be seen from several implementation variables in line with Van Meter and Van Horn theories, namely policy standards and targets, resources, interorganizational relationships, characteristics of implementing agents, social and economic conditions and disposition of implementors.

Public Service Policy Standards based on Law Number 25 of 2009 concerning Public Services (Undang-Undang No. 25 Tahun 2009 Tentang Pelayanan Publik., 2009) also the Decree of the Minister of Transportation No. 48 of 2002 concerning the operation of public airports (Peraturan Menteri Perhubungan No. 48 Tahun 2002 Tentang Penyelenggaraan Bandar Udara Umum, 2002) to realize the implementation of reliable and competent flight operations under the standards imposed by the Indonesian Standardization Agency (SNI) and the International Civil Aviation Organization (ICAO).

As with the Executive General Manager Decree about concerns about Service Standards at Sisingamangaraja XII International Airport (Keputusan General Manager Bandara Internasional Sisingamangaraja XII No.KEP.13.01/13/04/2018/007 Tentang Standar Pelayanan Di Bandara Internasional Sisingamangaraja XII, 2018). It targets the entire community/service user, which aims to provide satisfaction, comfort to the community so that It can be said that public service standards have clear standards and targets in their implementation and have provided excellent service to service users.

The most critical resources in implementing public service standards consist of three types of ownership and are still needed in the smooth process of implementing this public service standard, including human resources, budgetary resources, and physical resources.

Human resources which have been rehabilitated since the change of airport status to international are slowly improving, namely re-educating recruited resources that are not following their fields to fulfill the principle of "The Right Man On The Right Place." Physical resources in the form of facilities are by the needs of service users. Although the e-digital services delivered to the media are already functioning, they cannot be operated $100 \%$ because they are still in the process of development/improvement. Financial resources are impenetrable because they are the privacy of Angkasa Pura II and the airport itself. Each resource is already available but will still be needed to implement public service standards smoothly.

In implementing a policy, organizations need support and coordination from every organization involved. The relationship between Sisingamangaraja XII International Airport organizations has not gone well because so far, 
Sisingamangaraja XII International Airport is still only coordinating with Angkasa Pura II regularly, but it is possible to coordinate with other agencies. In addition, there is no coordination between Sisingamangaraja XII International Airport with partnerships because inter-airline parties carry out direct coordination with partnerships.

In this case, the characteristics of implementing agencies are organizations involved in the structure of public service standards. Related to this research, the Sisingamangaraja XII International Airport and the partnership (hotel/inn) and the airline and all relevant agencies as implementing agents are very helpful in implementing public service standards. In this case, all agents have a reciprocal relationship, in Sisingamangaraja XII International Airport, the partnership or the relevant implementing agency is takes part in supporting the process of implementing this program for the satisfaction of public services, and vice versa partnerships and implementing agencies cannot provide services to service users without competing with Sisingamangaraja XII International Airport.

The social and economic conditions of the community related to the existence of Sisingamangaraja XII International Airport have a positive impact and increase tourists to the Lake Toba National Tourism Strategy Area, both domestic tourists, and international tourists. In addition, the service user community can also receive good service standards because they feel the service quality of public policy standards. Also, there are political conditions, namely the situation related to the rejection of airport name change which was not accepted by the public even though there had been a decision to change the name.

The disposition of the implementor in this study consisted of responses attitudes of the implementor towards the policy implementation process. The responses of the implementers, which include Sisingamangaraja XII International Airport and related agencies, namely the implementers in serving the community, are excellent and responsive in responding to complaints from departing users or arriving users. In addition, the attitude of the implementers from the responses and attitudes shown by the implementors, it can be said that the disposition of the implementor is to support the implementation of public service standards.

\section{References}

Agustino, L. (2006). Dasar-Dasar Kebijakan Publik. Alfabeta.

Annex 14 - Aerodromes - Volume I: Aerodrome emergency planning section. (2018). International Civil Aviation Organization.

Bandara Silangit dan FL Tobing Tingkatkan Pelayanan. (2016, June 19). Koran Sindo. http://koran-

sindo.com/page/news/20160630/6/19/SilangitdanFLTobingTingkatkanPela yanan

Bungin, M. B. (2015). Metode Penelitian Sosial \& Ekonomi : Format-format Kuantitatif dan Kualitatif untuk Studi Sosiologi, Kebijakan Publik, Komunikasi, Manajemen, dan Pemasaran. Prenadamedia Group. 
Creswell, J. W., \& Creswell, J. D. (2018). Research design : qualitative, quantitative, and mixed methods approaches. In Research Defign: Qualitative, Quantitative, and Mixed M ethods Approaches (Fifth edit). SAGE Publications Inc.

De Oña, J., \& De Oña, R. (2015). Quality of service in public transport based on customer satisfaction surveys: A review and assessment of methodological approaches. Transportation Science, 49(3), 605-622. https://doi.org/10.1287/trsc.2014.0544

Dwiyanto, A. (2011). Manajemen pelayanan publik : peduli, inklusif, dan kolaboratif. Gadjah Mada University Press.

Holzer, M., \& Schwester, R. W. (2019). Public administration: An introduction. In Public Administration: An Introduction. Routledge, https://doi.org/10.4324/9780429507878

Idrus, M. (2009). Metode Penelitian Ilmu Sosial. Erlangga.

Indiahono, D. (2009). Kebijakan Publik. Gava Media.

Keputusan General Manager Bandara Internasional Sisingamangaraja XII No.KEP.13.01/13/04/2018/007 tentang Standar Pelayanan di Bandara Internasional Sisingamangaraja XII. (2018). General Manager Bandara Internasional Sisingamangaraja XII.

Morgeson, F. V. (2014). Citizen satisfaction: Improving government performance, efficiency, and citizen trust. In Citizen Satisfaction: Improving Government Performance, Efficiency, and Citizen Trust. Palgrave Macmillan. https://doi.org/10.1057/9781137047137

Peraturan Menteri Perhubungan No. 48 Tahun 2002 tentang Penyelenggaraan Bandar Udara Umum. (2002). Kementrian Perhubungan.

Peraturan Menteri Perhubungan No. 69 Tahun 2013 tentang Tatanan Kebandarudaraan Nasional. (2013). Kementrian Perhubungan.

Peraturan Pemerintah No. 70 Tahun 2001 tantang Kebandarudaraan. (2001). Repubik Indonesia.

Ridwan, J., \& Sudrajat, A. S. (2009). Hukum Administrasi Negara dan Kebijakan Pelayanan Publik. Nuansa.

Shafritz, J. M., Russell, E. W., Borick, C. P., \& Hyde, A. C. (2017). Introducing Public Administration. Taylor and Francis,.

Snellen, I. T. M. (2014). Foundations of Public Administration. In Theory and Practice (Vol. 1, Issue c). Eleven international publishing.

Subarsono, A. G. (2005). Analisis Kebijakan Publik Konsep, Teori dan Aplikasi. Pustaka Pelajar.

Undang-Undang No. 25 Tahun 2009 tentang Pelayanan Publik. (2009). Repubik Indonesia.

Van Meter, D. S., \& Van Horn, C. E. (1975). The Policy Implementation Process: A Conceptual Framework. Administration \& Society, 6(4), 445-488. 
https://doi.org/10.1177/009539977500600404

Wirtz, J., \& Lovelock, C. (2016). Services Marketing: People Technology Strategy. World Scientific Publishing. 